\title{
Physiological and nutritional responses in two highbush blueberry cultivars exposed to deficiency and excess of boron
}

\author{
C. Meriño-Gergichevich ${ }^{1 *}$, M. Reyes-Díaz ${ }^{1,2}$, J. Guerrero ${ }^{3}$, G. Ondrasek ${ }^{4}$
}

${ }^{1}$ Center of Plant, Soil Interaction and Natural Resources Biotechnology, Scientific and Technological Bioresource Nucleus (BIOREN-UFRO), Universidad de La Frontera, Temuco, Chile. ${ }^{2}$ Departamento de Ciencias Químicas y Recursos Naturales, Facultad de Ingeniería y Ciencias, Universidad de La Frontera, Temuco, Chile. ${ }^{3}$ Departamento de Producción Agropecuaria, Facultad de Ciencias Agropecuarias y Forestales, Universidad de La Frontera. ${ }^{4}$ Department of Soil Amelioration, Faculty of Agriculture, University of Zagreb, Zagreb, Croatia. *Corresponding author: cristian.merino@ufrontera.cl

\begin{abstract}
Boron (B) is an essential micronutrient required for physiological and biochemical processes in fruit crops such as highbush blueberry (Vaccinium corymbosum $\mathrm{L}$.), well adapted species to acidic soils $\left(\mathrm{pH}_{\text {water }} \leq 5.5\right)$ with relatively low B availability. However, an optimal range of B supplies is quite narrow, particularly among cultivars, making it easy to under- or over-fertilize which could lead to boron toxicity. Under controlled conditions, cultivars Brigitta and Legacy were grown in a peat moss substrate $(\mathrm{pH} 4.5)$ with five B concentrations $(0,50,200$, 400 and $800 \mu \mathrm{M})$. Plant biomass, nutrient concentration, water potential $\left(\Psi_{\text {leaf }}\right)$, oxidative stress and antioxidant activity were determined at $30 \mathrm{~d}$. Concentrations of 400 and $800 \mu \mathrm{M}$ B reduced shoot and root growth in both cultivars, and $800 \mu \mathrm{M} \mathrm{B}$ decreased $\Psi_{\text {leaf }}$ in Legacy and significantly increased it in Brigitta. Boron applied at 400 $\mu \mathrm{M}$ resulted in the highest B accumulation in leaves of Brigitta (5-fold) and Legacy (2-fold), whereas Brigitta roots showed up to $60 \%$ increased B accumulation in comparison with $50 \mu \mathrm{M} \mathrm{B}$, respectively. High B caused more severe oxidative stress in leaves of Legacy than B deficiency. The antioxidant activity was increased from 50 to $400 \mu \mathrm{M}$ B in both cultivars. Boron added at 400 and $800 \mu \mathrm{M}$ impaired physiological and biochemical performance probably due to toxicity, demonstrating that highbush blueberry in a genotype-dependent manner has relatively low B requirement.
\end{abstract}

Keywords: Antioxidant activity, boron nutrition, highbush blueberry, oxidative stress 


\section{Introduction}

Boron (B) is an essential micronutrient that has a key function in plant structure and is involved in a range of physiological and biochemical processes (Blevins and Lukaszewski, 1998; Herrera-Rodríguez et al., 2010; Landi et al., 2012; Yadegari, 2016). The critical levels between low and high B in plant tissues are narrow, but the $\mathrm{B}$ requirement range is highly variable among species and genotypes, with an optimum for one cultivar being either insufficient or toxic for other species or cultivars (Landi et al., 2012). There is little information regarding deficiency and excess of $\mathrm{B}$ in fruit plants grown in acidic soils, such as highbush blueberry (Vaccinium corymbosum L.). Wójcik (2005) reported optimal leaf B concentration in highbush blueberry cultivars Bluecrop and Jersey were below 15 and $37 \mathrm{mg} \mathrm{kg}^{-1} \mathrm{DW}$, respectively, classifying blueberry as a fruit species with controversial B requirements. In contrast, Caruso and Ramsdell, (1995) observed symptoms of B deficiency (including decreased leaf size and shoot growth) in highbush blueberry plants with leaves containing less than $20 \mathrm{mg}$ $\mathrm{kg}^{-1}$ DW. In White Smith gooseberry (Ribes grossularia L.) grown in soil with low B availability, Wójcik and Filipczak (2015) associated soil B fertilization (1 $\left.\mathrm{kg} \mathrm{ha}^{-1}\right)$ with greater B concentration in leaves $(>40$ $\left.\mathrm{mg} \mathrm{kg}{ }^{-1} \mathrm{DW}\right)$ compared with control plants without B fertilization that had $\sim 20 \mathrm{mg} \mathrm{B} \mathrm{kg}^{-1} \mathrm{DW}$ in leaves; higher leaf $\mathrm{B}$ concentration resulted in increased shoot length and improved production parameters.

Boron deficiency has been related to disorders in cell wall structure, reduced growth rate (particularly of shoots) (Camacho-Cristóbal et al., 2008; Herrera-Rodríguez et al., 2010; Miwa and Fujiwara, 2010), imbalances in nutrient status (Camacho-Cristóbal et al., 2008; Landi et al., 2012), disturbed water relations (Wimmer and Eichert 2013) and changes in antioxidant activity (Tewari et al., 2010; Dahajipour et al.,
2011). On the other hand, B toxicity is related to diminished plant growth, increased oxidative stress as evidenced by exacerbated lipid peroxidation, along with increases in activity of antioxidant compounds (Herrera-Rodriguez et al., 2010; Tewari et al., 2010; Gimeno et al., 2012; Kayaa and Ashraf, 2015). Pandey and Archana (2013) reported an accumulation of thiobarbituric acid-reactive substances in both leaves and roots of Brassica juncea under deficient ( 0.033 $\mathrm{mg} \mathrm{B} \mathrm{L}{ }^{-1}$ ) and excess boron (3.3 and $33 \mathrm{mg} \mathrm{B} \mathrm{L}^{-1}$ ) supply, suggesting oxidative damage due to excessive production of reactive oxygen species (ROS). Boron toxicity has also been associated with mottled interveinal chlorosis and scorching of leaf margins (Caruso and Ramsdell, 1995).

Boron-enriched soils are much rarer than B-deficient soils and concentrated particularly in the areas with the marine evaporates and marine argillaceous sediments (Nable et al., 1997). Plant B deficiency frequently occurs in acidic soils in temperate climates, which exhibit high precipitations and high leaching losses (Shorrocks, 1997). To remediate low B concentration, both soil and foliar applications are useful strategies to correct B levels; however, these practices could lead easily to over-fertilization (Wójcik, 2005). In plants such as flax (Linum ussitatissimum L.) grown in acidified hydroponic culture ( $\mathrm{pH} 4.5$ ), B treatments were deficient, normal and excessive at 4.5, 45 and $450 \mu \mathrm{M}$, respectively (Dahajipour et al., 2011). Moalemi et al. (2012) considered B concentrations of 1,10 and $1000 \mu \mathrm{M}$ as control, deficient and excessive, respectively, for marshmallow (Althaea officinalis L.) and reported that B deficiency and excess B led to increased concentration of phenolics and $\mathrm{H}_{2} \mathrm{O}_{2}$. Other authors reported normal B concentrations at $20 \mu \mathrm{M}$ in navel orange plants (Citrus sinensis) (Liu et al., 2014), and $50 \mu \mathrm{M}$ in laurel (Viburnum tinus) 
(Bañón et al., 2012). However, the question about which B supply could be deficient or toxic for highbush blueberry grown in acidic conditions remain unresolved.

In Chile, highbush blueberry is an important commercial crop, cultivated on 15,560 ha with a total fruit production of 91,000 $t$ during the season 201415 (Chilean Blueberry Committee, 2015). This fruit has received great interest due to its richness in antioxidants compared to other fruits, offering potential benefits for human health (Ehlenfeldt and Prior, 2001; Meriño-Gergichevich et al., 2015). In southern Chile, where acid Andisols $(\mathrm{pH} \leq 5.5)$ cover $2,600,000$ ha and represent the largest part of the arable area (Besoain, 1985), highbush blueberry is planted on 2,000 ha (Chilean Blueberry Committee, 2015); in these soils availability of many nutrients including B and phytotoxic aluminum (Al) can be a restrictive factor for highbush blueberry growth and yield. Traditionally, agricultural practices recommend B fertilization of blueberries to ensure greater fruit set and yield, as well as better quality parameters of marketable berries (Eichholz et al., 2011); however, an overestimation in B doses could lead to toxicity. In contrast to numerous studies on B deficiency in fruit plants (Liu et al., 2014), toxicity is poorly characterized for commercial fruit crops grown in acid soils, such gooseberry (Wójcik and Filipczak 2015) and highbush blueberry (Wójcik, 2005). Even it is usually assumed that critical ranges related to B deficiency, sufficiency and toxicity are narrow, those ranges vary among species and even among varieties of the same species (Herrera-Rodríguez et al., 2010; Landi et al., 2012).

The objective of this study was to determine the effects of different supplies of B on physiological and

\section{Material and Methods}

\subsection{Plant material and experimental conditions}

The study was carried out in a greenhouse at the Universidad de La Frontera, Temuco, La Araucanía Region, Chile. Highbush blueberry cultivars Brigitta and Legacy (one-year-old plants provided by Berries San Luis, Lautaro, Chile), frequently cultivated in southern Chile, were grown in a mixture of peat moss with coconut fibrer and vermiculite (Sociedad Rathgeb y Cía. Ltda, www.jardisen.cl) at $\mathrm{pH} 4.5$ under greenhouse conditions (air temperature $20-25{ }^{\circ} \mathrm{C}, 16 / 8 \mathrm{~h}$ light/dark period, air humidity $80 \%$ and photosynthetic photon flux density of $300 \mathrm{mmol}$ photons $\mathrm{m}^{-2}$ $\left.\mathrm{s}^{-1}\right)$. Plants were irrigated daily with adequate volume of Hoagland nutrient solution: $\mathrm{Ca}\left(\mathrm{NO}_{3}\right) 2 \mathrm{mM}, \mathrm{KNO}_{3}$ $3 \mathrm{mM}, \mathrm{MgSO}_{4} 1 \mathrm{mM}, \mathrm{KH}_{2} \mathrm{PO}_{4} 0.1 \mathrm{mM}, \mathrm{MnSO}_{4} 2 \mu \mathrm{M}$, $\mathrm{NH}_{4} \mathrm{NO}_{3} 1 \mathrm{mM},\left(\mathrm{NH}_{4}\right)_{6} \mathrm{Mo}_{7} \mathrm{O}_{24} 0.07 \mu \mathrm{M}, \mathrm{ZnSO}_{4} 1.6$ $\mu \mathrm{M}, \mathrm{CuSO}_{4} 0.4 \mu \mathrm{M}$, and Fe-EDTA $20 \mu \mathrm{M}$, containing either $0,50,200,400$ or $800 \mu \mathrm{M}$ of $\mathrm{B}$, equivalent to 0 , $3.10,12,25$ and $50 \mathrm{mg} \mathrm{L}^{-1} \mathrm{H}_{3} \mathrm{BO}_{3}$, respectively. The study considered the following measurements: plant biomass, leaf and root nutrient concentration, water potential, oxidative stress, and radical scavenging activity (RSA). After 30 days, plant leaves and roots were harvested, one-half was used for chemical (inorganic) and physiological analyses and another half was stored at $-80^{\circ} \mathrm{C}$ for biochemical analyses.

\subsection{Plant biomass}

At harvest, leaves and root plants were dried by placing them at $70{ }^{\circ} \mathrm{C}$ in a forced-air oven for $48 \mathrm{~h}$. To determine mean relative growth rate (MRGR), the procedure of Hoffmann and Poorter (2002) was applied as follows: 


$$
\text { MRGR }=\frac{(\ln W 2)-(\ln W 1)}{\mathrm{t} 2-\mathrm{t} 1}
$$

where $\mathrm{W} 1$ and $\mathrm{W} 2$ represent the dry weight at time 0 $\mathrm{d}(\mathrm{t} 1)$ and $30 \mathrm{~d}(\mathrm{t} 2)$ respectively.

\subsection{Leaf water potential}

Leaf water potential $\left(\Psi_{\text {leaf }}\right)$ was measured using a pressure chamber PMS (model 1000, Instrument Co., Corvallis, OR, USA), following the recommendations by Hsiao (1990). Measurements were made at midday, between 13:30 and 15:30 h, on shaded leaves enclosed in plastic bags laminated with aluminum foil for at least 1 hour (h).

\subsection{Chemical analyses}

Nutrient concentrations were determined in the leaves and roots according to the method described by Sadzawka et al. (2007), using a simultaneous multi-element atomic absorption spectrophotometer (Perkin-Elmer 3110, Wellesley, USA).

\subsection{Lipid peroxidation}

The level of lipid peroxidation (LP) was expressed as malondialdehyde (MDA) concentration (nmol MDA $\mathrm{g}^{-1} \mathrm{FW}$ ) and determined as 2-thiobarbituric acid reactive-substances (TBARS), according to the protocol modified by Du and Bramlage, (1992). Thus, the absorbance was spectrophotometrically measured at 532,600 and $440 \mathrm{~nm}$ in order to correct the interference caused by TBARS-sugar complexes.

\subsection{Radical scavenging activity}

Fresh leaves and root samples were snap-frozen in liquid nitrogen, powdered in a mortar, homogenized in $1 \mathrm{~mL}$ of $80 \%(\mathrm{v} / \mathrm{v})$ methanol, and centrifuged at $10,000 \mathrm{rpm}$ for $5 \mathrm{~min}\left(\right.$ at $4{ }^{\circ} \mathrm{C}$ ). The supernatant was collected and stored at $-80^{\circ} \mathrm{C}$ until analysis. Radical scavenging activity (RSA) of roots and leaves was assayed using the 2.2-diphenyl-1-picryl-hydrazyl (DPPH) scavenging method as described by Chinnici et al. (2004). Absorbance was measured at $515 \mathrm{~nm}$ using Trolox as standard.

\subsection{Experimental design and statistical analyses}

The experiment was arranged in a split-plot design with two cultivars $\mathrm{x}$ five B treatment in four replicates each. All data were tested by Kolmogorov-Smirnov test for homogeneity of variances. A two-way analysis of variance (ANOVA) and Tukey test were used to determine significance of differences between the means with a significance level at $\mathrm{P} \leq 0.05$. All statistical analyses were performed with Sigma Stat 3.1 (SPSS ${ }^{\circledR}$ Inc., Chicago, IL, USA).

\subsection{Plant biomass and water potential}

After 30 days, both main effects (B treatment and cultivar) significantly influenced MRGR (mg DW day ${ }^{-1}$ ), but the interaction was not significant (Table 1). Significantly decreased MRGR was found in Brigitta and Legacy, with a reduction up to $75 \%$ and $90 \%$ respectively, under high $\mathrm{B}(800 \mu \mathrm{M})$ compared to 50 and $200 \mu \mathrm{M}$ B ( $\mathrm{P} \leq 0.05$; Table 2). In Brigitta, a significant decrease $(75 \%)$ in MRGR for deficient $\mathrm{B}(0 \mu \mathrm{M})$ was found in comparison to $50 \mu \mathrm{M}$, maximal MRGR values, up to 8.8 in Brigitta and $10.8 \mathrm{mg} \mathrm{DW} \mathrm{day}{ }^{-1}$ for Legacy were observed in plants grown at $50 \mu \mathrm{M} \mathrm{B}$ (Table 2; $\mathrm{P} \leq 0.05$ ).

No significant interactions between $\mathrm{B}$ and cultivar were found for dry weight (DW) production of root and leaves. Compared to high $\mathrm{B}(800 \mu \mathrm{M})$, the other treatments showed increased leaf DW production in 
Brigitta ( $\mathrm{P} \leq 0.05$; Table 2), eg. up to $20 \%$ and $24 \%$ at 0 and $50 \mu \mathrm{M} \mathrm{B}$, respectively (Table 2). In Legacy, leaf DW was reduced by $56 \%$ at $800 \mu \mathrm{M}$ compared to $50 \mu \mathrm{M} \mathrm{B}(\mathrm{P} \leq 0.05)$. Cultivars differed significantly with respect to root DW (Table 1), whereby Brigitta for all treatments showed on average $85 \%$ greater root DW production than Legacy (Table 2). The highest root DW in Brigitta was noted in the $50 \mu \mathrm{M}$
B treatment (Table 2; $\mathrm{P} \leq 0.05$ ). Regarding the root/ shoot ratio, the interaction $\mathrm{B} x$ cultivar was nonsignificant and the cultivar was the main factor that influenced this parameter (Table 1). The lowest root/shoot ratio in Brigitta was observed at $0 \mu \mathrm{M}$ B $(\mathrm{P} \leq 0.05)$, whereas in Legacy significant increases were registered at 400 and $800 \mu \mathrm{MB}$ compared with the $50 \mu \mathrm{M}$ B (Table 2).

Table 1. ANOVA of the mean relative growth rate (MRGR), root:shoot ratio, leaf water potential $\left(\Psi_{\text {leaf }}\right)$, dry matter (DM), mineral status, and oxidative stress assessed by lipid peroxidation (LP) and radical scavenging activity (RSA).

\begin{tabular}{|c|c|c|c|c|c|c|}
\hline \multirow[b]{3}{*}{ Growth parameter } & \multicolumn{6}{|c|}{ Source of variation } \\
\hline & \multicolumn{2}{|c|}{ Boron (B) } & \multicolumn{2}{|c|}{ Cultivar (c) } & \multicolumn{2}{|c|}{$\mathrm{B} \times \mathrm{c}$} \\
\hline & & & & & & \\
\hline MRGR (mg DW d $\left.\mathrm{d}^{-1}\right)$ & \multicolumn{2}{|c|}{$3.6^{*}$} & \multicolumn{2}{|c|}{$6.1^{*}$} & \multicolumn{2}{|c|}{$0.9 \mathrm{~ns}$} \\
\hline Root/shoot ratio & \multicolumn{2}{|c|}{$3.1^{*}$} & \multicolumn{2}{|c|}{$225 * *$} & \multicolumn{2}{|c|}{$0.9 \mathrm{~ns}$} \\
\hline \multirow[t]{2}{*}{$\Psi_{\text {leaf }}(\mathrm{MPa})$} & \multicolumn{2}{|c|}{$10 * * *$} & \multicolumn{2}{|c|}{$128 * * *$} & \multicolumn{2}{|c|}{$36 * * *$} \\
\hline & Leaf & Roots & Leaf & Roots & Leaf & Roots \\
\hline DW $\left(\right.$ g plant $\left.^{-1}\right)$ & $7.4 * * *$ & $1.3 \mathrm{~ns}$ & $135 * * *$ & $479 * * *$ & $1.6 \mathrm{~ns}$ & $0.4 \mathrm{~ns}$ \\
\hline \multicolumn{7}{|l|}{ Mineral concentration $\left(\mathrm{mg} \mathrm{kg}^{-1}\right)$} \\
\hline & Leaf & Roots & Leaf & Roots & Leaf & Roots \\
\hline B & $40^{* * *}$ & $7.2 * * *$ & $13^{* * * *}$ & $58 * * *$ & $23^{* * *}$ & $3.8^{* * *}$ \\
\hline $\mathrm{Al}$ & $0.9 \mathrm{~ns}$ & $0.5 \mathrm{~ns}$ & $5.2^{*}$ & $17 * * *$ & $0.6 \mathrm{~ns}$ & $0.9 \mathrm{~ns}$ \\
\hline $\mathrm{Ca}$ & $3.9^{*}$ & $4.2 * *$ & $46 * * *$ & $40 * * *$ & $5.2 * *$ & $1.5 \mathrm{~ns}$ \\
\hline $\mathrm{Mg}$ & $1.3 \mathrm{~ns}$ & $4.5^{* *}$ & $6.5^{* *}$ & $194 * * *$ & $1.6 \mathrm{~ns}$ & $5.9^{* * *}$ \\
\hline K & $25^{* * *}$ & $1.2 \mathrm{~ns}$ & $7.8 * *$ & $4.7 * *$ & $51 * * *$ & $3.0^{*}$ \\
\hline $\mathrm{Na}$ & $13^{* * *}$ & $1.2 \mathrm{~ns}$ & $33^{* * * *}$ & $39^{* * *}$ & $8.8^{* * *}$ & $4.9^{* * k}$ \\
\hline \multicolumn{7}{|l|}{ Antioxidant parameter } \\
\hline Lipid peroxidation (nmol $\mathrm{MDA} \mathrm{g}^{-1} \mathrm{FW}$ ) & $0.41 \mathrm{~ns}$ & $7.65^{* * *}$ & $0.56 \mathrm{~ns}$ & $61.98 * * *$ & $6.18 * * *$ & $8.29^{* * * *}$ \\
\hline RSA (TE g $\left.^{-1} \mathrm{FW}\right)$ & $0.51 \mathrm{~ns}$ & $0.74 \mathrm{~ns}$ & $7.06^{* * *}$ & $32.52 * * *$ & $4.29 * *$ & $1.03 \mathrm{~ns}$ \\
\hline
\end{tabular}

Significance designated as ns: not significant; ${ }^{\mathrm{P}} \leq 0.05 ; * * \mathrm{P} \leq 0.01 ; * * * \mathrm{P} \leq 0.001$. 
Table 2 Mean relative growth rate (MRGR), leaf and root dry weight and leaf water potential $\left(\Psi_{\text {leaf }}\right)$ in two highbush blueberry cultivars subjected to different B treatments in substrate after 30 days. Values are means of four replicates \pm S.E. Different uppercase letters indicate significant differences $(\mathrm{P} \leq 0.05)$ between cultivars for the same treatment. Different lowercase letters indicate statistically significant differences $(\mathrm{P} \leq 0.05)$ among $\mathrm{B}$ rates for the same cultivar.

\begin{tabular}{|c|c|c|c|c|c|c|c|c|c|c|}
\hline \multirow[b]{3}{*}{ Parameter } & \multicolumn{10}{|c|}{ Boron supply $(\mu \mathrm{M})$} \\
\hline & \multicolumn{2}{|c|}{0} & \multicolumn{2}{|c|}{50} & \multicolumn{2}{|c|}{200} & \multicolumn{2}{|c|}{400} & \multicolumn{2}{|c|}{800} \\
\hline & Brigitta & Legacy & Brigitta & Legacy & Brigitta & Legacy & Brigitta & Legacy & Brigitta & Legacy \\
\hline $\begin{array}{l}\text { MRGR } \\
\left(\mathrm{mg} \mathrm{DW} \mathrm{d}^{-1}\right)\end{array}$ & $2.1 \pm 0.30 \mathrm{bB}$ & $9.4 \pm 1.8 \mathrm{aA}$ & $8.8 \pm 1.7 \mathrm{aA}$ & $10.8 \pm 2.1 \mathrm{aA}$ & $1.5 \pm 0.4 \mathrm{bcB}$ & $9.2 \pm 2.6 \mathrm{aA}$ & $1.2 \pm 0.5 \mathrm{cB}$ & $2.9 \pm 0.2 \mathrm{bA}$ & $1.1 \pm 0.2 \mathrm{cA}$ & $0.9 \pm 0.1 \mathrm{cA}$ \\
\hline $\begin{array}{l}\text { Leaf DW } \\
\text { (g) plant }{ }^{-1}\end{array}$ & $8.6 \pm 0.44 \mathrm{aA}$ & $4.2 \pm 0.1 \mathrm{bB}$ & $9.0 \pm 0.6 \mathrm{aA}$ & $6.5 \pm 0.1 \mathrm{aB}$ & $8.2 \pm 0.8 \mathrm{bA}$ & $3,8 \pm 0,5 \mathrm{bB}$ & $8.3 \pm 0.9 \mathrm{bA}$ & $4.0 \pm 0.2 \mathrm{bB}$ & $6.8 \pm 0.3 \mathrm{cA}$ & $2.8 \pm 0.1 \mathrm{cB}$ \\
\hline $\begin{array}{l}\text { Root DW } \\
\text { (g) plant }{ }^{-1}\end{array}$ & $6.0 \pm 0.3 \mathrm{bA}$ & $0.7 \pm 0.0 \mathrm{bB}$ & $7.2 \pm 0.5 \mathrm{aA}$ & $1.2 \pm 0.1 \mathrm{aB}$ & $6.1 \pm 0.4 \mathrm{bA}$ & $0.8 \pm 0.1 \mathrm{bB}$ & $6.6 \pm 0.9 \mathrm{bA}$ & $0.9 \pm 0.1 \mathrm{aB}$ & $6.1 \pm 0.3 \mathrm{bA}$ & $1.0 \pm 0.1 \mathrm{aB}$ \\
\hline Root/shoot & $0.7 \pm 0.0 \mathrm{bA}$ & $0.1 \pm 0.0 \mathrm{bB}$ & $0.8 \pm 0.0 \mathrm{aA}$ & $0.1 \pm 0.0 \mathrm{bB}$ & $0.7 \pm 0.1 \mathrm{aA}$ & $0.1 \pm 0.0 \mathrm{bB}$ & $0.8 \pm 0.0 \mathrm{aA}$ & $0.2 \pm 0.0 \mathrm{aB}$ & $0.9 \pm 0.0 \mathrm{aA}$ & $0.4 \pm 0.0 \mathrm{aB}$ \\
\hline
\end{tabular}

The water potential $\left(\Psi_{\text {leaf }}\right)$ was influenced by the boron $\mathrm{x}$ cultivar interaction $(\mathrm{P} \leq 0.001)$ (Table 1). Cultivars showed similar $\Psi_{\text {leaf }}$ at $0 \mu \mathrm{M}$ B but differed in treatments containing $50 \mu \mathrm{M}$ B or higher (Figure 1). Boron application improved $\Psi_{\text {leaf }}$ in Brigitta from -0.629 to $-0.283 \mathrm{MPa}$ at $800 \mu \mathrm{M}(\mathrm{P} \leq 0.001)$ and Legacy showed decreased $\Psi_{\text {leaf }}$ at $800 \mu \mathrm{M} \mathrm{B}$ compared to $0 \mu \mathrm{M} \mathrm{B}(-0.575$ and $-0.683 \mathrm{MPa}$, respectively) $(\mathrm{P}=0.03)$.

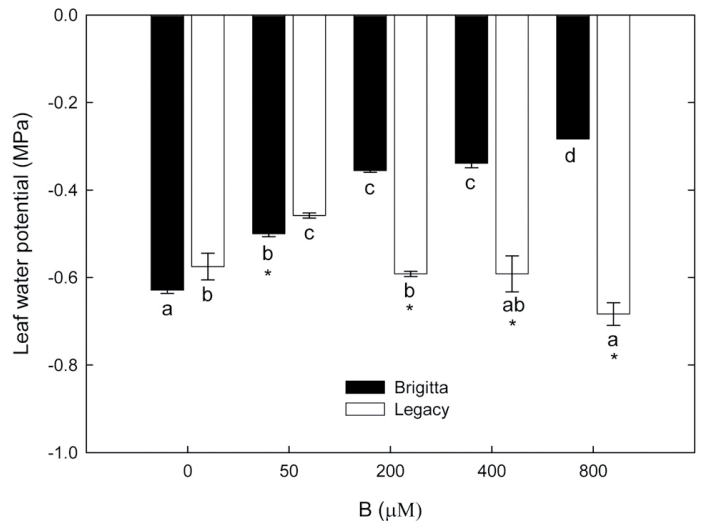

Figure 1. Changes in leaf water potential $\left(\Psi_{\text {leaf }}\right)$ in two highbush blueberry cultivars subjected to different $\mathrm{B}$ treatments in substrate after 30 days. Values represent the average of four replicates \pm SE. Different uppercase letters indicate significant differences $(\mathrm{P} \leq 0.05)$ between cultivars for the same treatment. Different lowercase letters indicate significant differences $(\mathrm{P} \leq 0.05)$ among treatments for the same cultivar.

\subsection{Mineral concentration in leaves and roots}

The main factors B and cultivar as well as their interaction significantly influenced B concentration ( $\mathrm{mg} \mathrm{kg}^{-1}$ DW) in leaves and roots of blueberry plants (Table 1). Non-significant differences were observed in leaves of both cultivars under treatments 0 and $50 \mu \mathrm{M} \mathrm{B}$; however, at $200 \mu \mathrm{M}$ Legacy accumulated $98 \%$ more B than Brigitta $(\mathrm{P} \leq 0.05)$. With higher $\mathrm{B}$ concentration 400 and $800 \mu \mathrm{M}$, was Brigitta the cultivar that showed the greatest B in leaves (Table 3) with maximal value of $240 \mathrm{mg} \mathrm{B} \mathrm{kg}{ }^{1}$ DW (ranges from 196 to $296 \mathrm{mg} \mathrm{B} \mathrm{kg}^{1}$ DW) and $114 \mathrm{mg} \mathrm{B} \mathrm{kg}^{1} \mathrm{DW}$ (ranges from 73 to $138 \mathrm{mg}$ $\left.\mathrm{B} \mathrm{kg}{ }^{1} \mathrm{DW}\right)$ respectively $(\mathrm{P} \leq 0.05$; Table 3$)$. In roots, $\mathrm{B}$ $\mathrm{x}$ cultivar interaction was significant for Brigitta where $\mathrm{B}$ in roots were gradually increased under treatments $200 \mu \mathrm{M}(44 \%)$ and $400 \mu \mathrm{M}(60 \%)$, in comparison to B $50 \mu \mathrm{M}(\mathrm{P} \leq 0.05)$, whereas in Legacy no changes in $\mathrm{B}$ accumulation were observed (Table 3 ). 
Table 3. Mineral concentrations in leaves and roots of highbush blueberry cultivars subjected to different B treatments in substrate after 30 days. Values are means of four analytical replicates \pm S.E. Different uppercase letters indicate significant differences $(\mathrm{P} \leq 0.05)$ between cultivars for the same treatment. Different lowercase letters indicate significant differences $(\mathrm{P} \leq 0.05)$ among treatments for the same cultivar.

\begin{tabular}{|c|c|c|c|c|c|c|c|c|c|c|}
\hline \multirow{3}{*}{$\begin{array}{l}\text { Mineral } \\
\text { status }\end{array}$} & \multicolumn{10}{|c|}{ Boron supply $(\mu \mathrm{M})$} \\
\hline & \multicolumn{2}{|r|}{0} & \multicolumn{2}{|c|}{50} & \multicolumn{2}{|c|}{200} & \multicolumn{2}{|c|}{400} & \multicolumn{2}{|c|}{800} \\
\hline & Brigitta & Legacy & Brigitta & Legacy & Brigitta & Legacy & Brigitta & Legacy & Brigitta & Legacy \\
\hline \multicolumn{11}{|l|}{ Leaf } \\
\hline $\mathrm{B}\left(\mathrm{mg} \mathrm{kg}^{-1}\right)$ & $47 \pm 1.0 \mathrm{cA}$ & $55 \pm 3.8 \mathrm{cA}$ & $48 \pm 3.4 \mathrm{cA}$ & $49 \pm 2.7 \mathrm{cA}$ & $52 \pm 2.7 \mathrm{cB}$ & $103 \pm 21.4 \mathrm{aA}$ & $240 \pm 20.9 \mathrm{aB}$ & $96 \pm 5.5 \mathrm{aA}$ & $114 \pm 14.3 \mathrm{bB}$ & $70 \pm 1.7 \mathrm{bA}$ \\
\hline $\mathrm{Al}\left(\mathrm{mg} \mathrm{kg}^{-1}\right)$ & $204 \pm 13 \mathrm{aA}$ & $176 \pm 5.2 \mathrm{aA}$ & $211 \pm 10 \mathrm{aA}$ & $191 \pm 18 \mathrm{aA}$ & $189 \pm 14 \mathrm{aA}$ & $153 \pm 6.7 \mathrm{aA}$ & $175 \pm 25 \mathrm{aA}$ & $180 \pm 24 \mathrm{aA}$ & $209 \pm 13 \mathrm{aA}$ & $165 \pm 23 \mathrm{aA}$ \\
\hline $\mathrm{Ca}\left(\mathrm{g} \mathrm{kg}^{-1}\right)$ & $7.30 \pm 0.14 \mathrm{aA}$ & $7.16 \pm 0.21 \mathrm{bA}$ & $7.42 \pm 0.22 \mathrm{aA}$ & $8.23 \pm 0.31 \mathrm{abA}$ & $7.23 \pm 0.23 \mathrm{aB}$ & $9.46 \pm 0.52 \mathrm{aA}$ & $7.06 \pm 0.28 \mathrm{aB}$ & $9.12 \pm 0.56 \mathrm{aA}$ & $6.49 \pm 0.21 \mathrm{aB}$ & $8.44 \pm 0.34 \mathrm{abA}$ \\
\hline $\mathrm{Mg}\left(\mathrm{g} \mathrm{kg}^{-1}\right)$ & $1.77 \pm 0.03 \mathrm{aB}$ & $2.02 \pm 0.04 \mathrm{aA}$ & $1.87 \pm 0.03 \mathrm{aA}$ & $1.74 \pm 0.76 \mathrm{aA}$ & $1.95 \pm 0.08 \mathrm{aA}$ & $2.05 \pm 0.18 \mathrm{aA}$ & $1.83 \pm 0.06 \mathrm{aB}$ & $2.16 \pm 0.14 \mathrm{aA}$ & $1.83 \pm 0.06 \mathrm{aB}$ & $2.13 \pm 0.17 \mathrm{aA}$ \\
\hline $\mathrm{K}\left(\mathrm{g} \mathrm{kg}^{-1}\right)$ & $13.30 \pm 0.45 \mathrm{bA}$ & $12.26 \pm 0.79 \mathrm{cA}$ & $12.94 \pm 0.68 \mathrm{bB}$ & $16.64 \pm 0.67 \mathrm{bA}$ & $12.72 \pm 0.44 \mathrm{bB}$ & $25.61 \pm 0.60 \mathrm{aA}$ & $16.66 \pm 1.30 \mathrm{aA}$ & $9.96 \pm 0.36 \mathrm{cB}$ & $14.41 \pm 0.94 \mathrm{bA}$ & $12.10 \pm 0.79 \mathrm{cB}$ \\
\hline $\mathrm{Na}\left(\mathrm{g} \mathrm{kg}^{-1}\right)$ & $0.58 \pm 0.03 \mathrm{aB}$ & $0.90 \pm 0.10 \mathrm{bA}$ & $0.55 \pm 0.02 \mathrm{aA}$ & $0.67 \pm 0.05 \mathrm{cA}$ & $0.57 \pm 0.01 \mathrm{aB}$ & $1.16 \pm 0.03 \mathrm{aA}$ & $0.52 \pm 0.04 \mathrm{aA}$ & $572 \pm 0.09 \mathrm{cA}$ & $5.03 \pm 0.04 \mathrm{aA}$ & $5.28 \pm 0.06 \mathrm{cA}$ \\
\hline \multicolumn{11}{|l|}{ Roots } \\
\hline B $\left(\mathrm{mg} \mathrm{kg}^{-1}\right)$ & $21 \pm 0.8 \mathrm{bA}$ & $14 \pm 0.5 \mathrm{aB}$ & $25 \pm 1.9 \mathrm{bA}$ & $15 \pm 1.9 \mathrm{aB}$ & $36 \pm 7.2 \mathrm{aA}$ & $16 \pm 0.9 \mathrm{aB}$ & $40 \pm 1.8 \mathrm{aA}$ & $18 \pm 0.2 \mathrm{aB}$ & $22 \pm 2.4 \mathrm{bA}$ & $16 \pm 1.3 \mathrm{aA}$ \\
\hline $\mathrm{Al}\left(\mathrm{mg} \mathrm{kg}^{-1}\right)$ & $3163 \pm 340 \mathrm{aA}$ & $1675 \pm 156 \mathrm{aB}$ & $2618 \pm 492 \mathrm{aA}$ & $1635 \pm 274 \mathrm{aA}$ & $2765 \pm 532 \mathrm{aA}$ & $1831 \pm 209 \mathrm{aA}$ & $2462 \pm 266 \mathrm{bA}$ & $1400 \pm 336 \mathrm{aB}$ & $2176 \pm 377 \mathrm{bA}$ & $2011 \pm 387 \mathrm{aA}$ \\
\hline $\mathrm{Ca}\left(\mathrm{g} \mathrm{kg}^{-1}\right)$ & $5.12 \pm 0.44 \mathrm{bA}$ & $4.24 \pm 0.13 \mathrm{bA}$ & $6.77 \pm 0.26 \mathrm{abA}$ & $4.39 \pm 0.55 \mathrm{bB}$ & $8.17 \pm 0.33 \mathrm{aA}$ & $5.11 \pm 0.70 \mathrm{aB}$ & $6.56 \pm 0.14 \mathrm{abA}$ & $4.64 \pm 0.47 \mathrm{bB}$ & $6.18 \pm 0.76 \mathrm{bA}$ & $4.82 \pm 0.47 \mathrm{bA}$ \\
\hline $\operatorname{Mg}\left(\mathrm{g} \mathrm{kg}^{-1}\right)$ & $1.73 \pm 0.16 \mathrm{bA}$ & $1.30 \pm 0.11 \mathrm{aB}$ & $2.37 \pm 0.04 \mathrm{aA}$ & $1.31 \pm 0.09 \mathrm{aB}$ & $2.61 \pm 0.15 \mathrm{aA}$ & $1.29 \pm 0.08 \mathrm{aB}$ & $2.36 \pm 0.02 \mathrm{aA}$ & $1.18 \pm 0.06 \mathrm{aB}$ & $2.09 \pm 0.16 \mathrm{bA}$ & $1.40 \pm 0.06 \mathrm{aB}$ \\
\hline $\mathrm{K}\left(\mathrm{g} \mathrm{kg}^{-1}\right)$ & $2.45 \pm 0.08 \mathrm{aA}$ & $2.40 \pm 0.40 \mathrm{abA}$ & $2.50 \pm 0.11 \mathrm{aA}$ & $2.30 \pm 0.22 \mathrm{abA}$ & $2.83 \pm 0.16 \mathrm{aA}$ & $2.00 \pm 0.13 \mathrm{bB}$ & $2.96 \pm 0.12 \mathrm{aA}$ & $2349 \pm 132 a b B$ & $2545 \pm 142 \mathrm{aA}$ & $2916 \pm 201 \mathrm{aA}$ \\
\hline $\mathrm{Na}\left(\mathrm{g} \mathrm{kg}^{-1}\right)$ & $0.50 \pm 0.02 \mathrm{bA}$ & $0.36 \pm 0.04 \mathrm{aB}$ & $0.41 \pm 0.01 \mathrm{bA}$ & $0.44 \pm 0.01 \mathrm{aA}$ & $0.57 \pm 0.04 \mathrm{aA}$ & $0.36 \pm 0.02 \mathrm{aB}$ & $0.634 \pm 0.03 \mathrm{aA}$ & $359 \pm 20 \mathrm{aB}$ & $496 \pm 35 \mathrm{bA}$ & $380 \pm 68 \mathrm{aB}$ \\
\hline
\end{tabular}

There were significant $\mathrm{B} x$ cultivar interactions for $\mathrm{Ca}, \mathrm{K}$ and $\mathrm{Na}$ concentrations in leaves, whereas in roots significant interactive effects of $\mathrm{B} x$ cultivar influenced $\mathrm{Mg}, \mathrm{Na}$ and $\mathrm{K}$ accumulation (Table 1). Boron treatments did not affect $\mathrm{Al}$ in leaves of cultivars, whereas in roots of Brigitta the accumulation of this cation was decreased at $400 \mu \mathrm{M} \mathrm{B}$ (Table 3). Contrary, $\mathrm{Ca}$ concentration in leaves was significantly increased in Legacy from $200 \mu \mathrm{M} \mu \mathrm{M}$ B in comparison to $0 \mu \mathrm{M}$ B treatment (Table 3).

\subsection{Lipid peroxidation and radical scavenging ac- tivity}

After 30 days, lipid peroxidation in leaves and roots showed a significant $\mathrm{B}$ x cultivar interaction (Table 1). Leaves of Brigitta showed a maximal decrease in lipid peroxidation at $200 \mu \mathrm{M} \mathrm{B}$ in comparison to the $0 \mu \mathrm{M} \mathrm{B}(64 \%)$ and $800 \mu \mathrm{M}(55 \%)$ treatments in lipid peroxidation at $200 \mu \mathrm{M} \mathrm{B}$ in comparison to the $0 \mu \mathrm{M} \mathrm{B}(64 \%)$ and $800 \mu \mathrm{M}(55 \%)$ treatments ( $\mathrm{P} \leq 0.05$; Figure 2), whereas Legacy showed a significant increased lipid peroxidation in leaves from 200 to $800 \mu \mathrm{M}$ B. Legacy exhibited an increased lipid peroxidation in leaves $(45 \%)$ treated with 400 and $800 \mu \mathrm{M}$, in comparison to the treatments 0 and $50 \mu \mathrm{M} \mathrm{B}(\mathrm{P} \leq 0.05)$. In roots of Brigitta a higher lipid peroxidation than in Legacy was found in all treatments $(\mathrm{P} \leq 0.05)$, except in roots at $50 \mu \mathrm{M} \mathrm{B}$ (Figure 2). In Brigitta lipid peroxidation was reduced up to $70 \%$ in roots subjected to $50 \mu \mathrm{M} \mathrm{B}$ compared to the other treatments $(\mathrm{P} \leq 0.05)$. However, roots of Legacy were not affected by $\mathrm{B}$ treatment (Figure 2). 


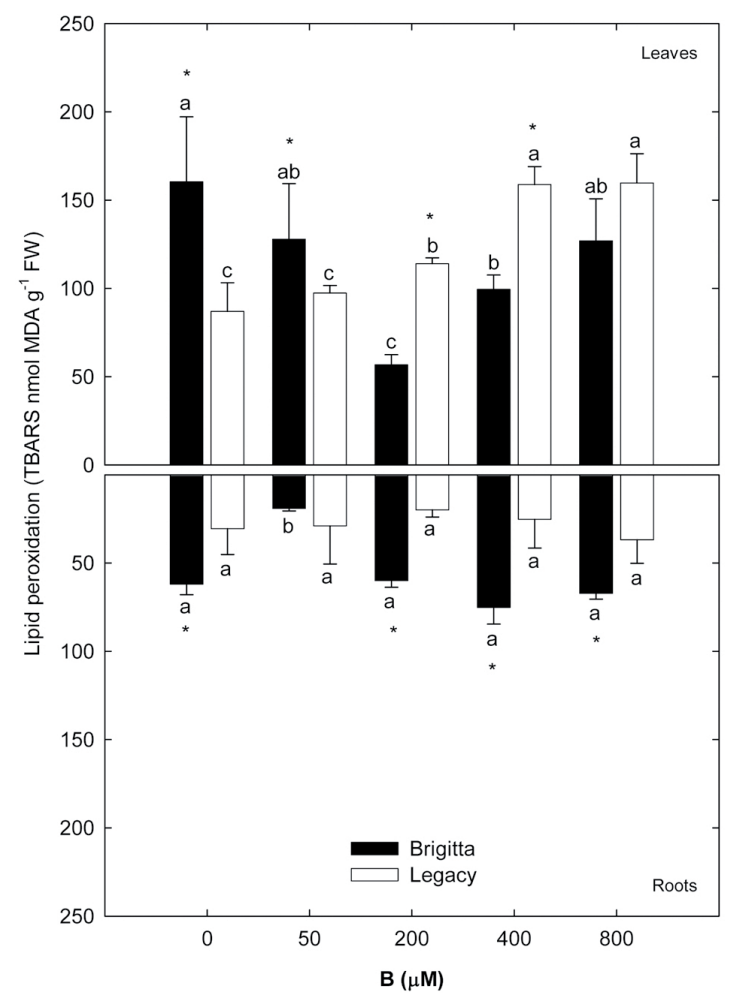

Figure 2. Lipid peroxidation (LP) measured as malondialdehyde content in leaves and roots of two highbush blueberry cultivars subjected to different B treatments in substrate after 30 days. Values represent the mean of four replicates \pm S.E. Different uppercase letters indicate significant differences $(\mathrm{P} \leq 0.05)$ between cultivars for the same treatment. Different lowercase letters indicate significant differences $(\mathrm{P} \leq 0.05)$ among treatments for the same cultivar.

There was the significant interaction influencing radical scavenging activity (RSA) in leaves (Table 1). The RSA in leaves increased by $8-11 \%$ from 50 to $400 \mu \mathrm{M}$ $\mathrm{B}$ in Brigitta (Figure 3; $\mathrm{P} \leq 0.05$ ). The $\mathrm{B}$ treatment at 200 and $400 \mu \mathrm{M}$ significantly increased RSA in leaves of Legacy compared to the $0 \mu \mathrm{M}$ B treatment. In roots, the interaction $\mathrm{B} x$ cultivar was not significant $(\mathrm{P} \leq 0.05)$. Increased $\mathrm{B}$ additions improved RSA in Brigitta roots; moreover, Brigitta exhibited higher RSA in roots than Legacy in all treatments (Figure 3; $\mathrm{P} \leq 0.05)$.

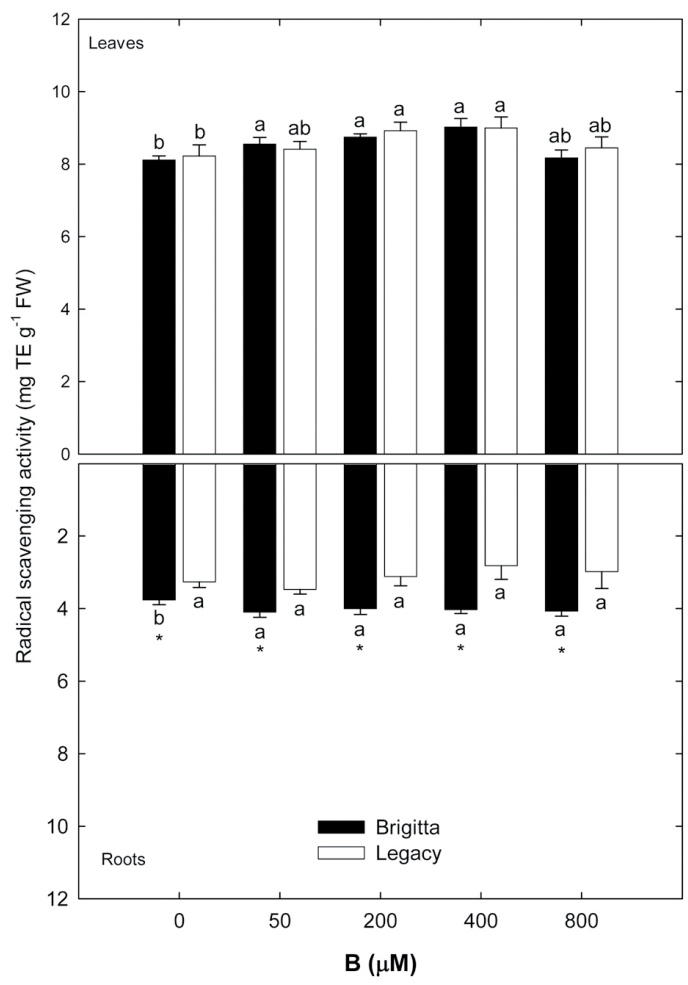

Figure 3. Radical scavenging activity in leaves and roots of two highbush blueberry cultivars subjected to different $\mathrm{B}$ treatments in substrate after 30 days. Values represent the mean of four replicates \pm S.E. Different uppercase letters indicate significant differences $(\mathrm{P} \leq 0.05)$ between cultivars for the same treatment. Different lowercase letters indicate significant differences $(\mathrm{P} \leq 0.05)$ among treatments for the same cultivar. 


\section{Discussion}

In our studied highbush blueberry plants, the cultivars achieved best MRGR at $50 \mu \mathrm{M}$, whereas significant growth depression occurred at high B supply, resulting that excessive B application decreased plant growth more severely than low B. Similar findings were reported by Nasim et al., (2015) for barley (Hordeum vulgare L.) cultivar Clipper, with excess B supply (3 $\mathrm{mg} \mathrm{kg}^{-1}$ soil) resulting in a significant decrease in plant dry matter. In the present study, cultivar Brigitta had higher leaf and root dry weight than Legacy at high $B$ rates, such B tolerance has been reported for vegetative tissues in fruit crops such as (Malus domestica Borkh) (Molassiotis et al., 2006). Tolerance to B excess is associated with enhanced expression and activity of specific transmembrane B exporters (BORs) and nodulin-26-like intrinsic proteins (NIPs) capable of excluding $\mathrm{B}$ at the root-cell plasma membranes (Miwa and Fuyiwara, 2010; Landi et al., 2012).

Decreased DM production at high B was more accentuated in shoots than roots, particularly in Legacy, where the root/shoot ratio was higher at 400 and 800 $\mu \mathrm{M} \mathrm{B}$ than 0 and $50 \mu \mathrm{M} \mathrm{B}$. These findings can be explained by strong permeability of the plasma membrane lipid bilayers to $\mathrm{H}_{3} \mathrm{BO}_{3}$, followed by transport upward via xylem to the leaf tissues where B may accumulate and cause visual B-toxicity symptoms (Herrera-Rodríguez et al., 2010; Miwa and Fujiwara, 2010; Landi et al., 2012).

According to Wimmer and Eichert (2013), B deficiency affects water relations by altering root uptake, water transport through xylem and impairment transpiration in leaves. In our study both cultivars showed more negative water potential under $0 \mu \mathrm{M}$ compared with treatment $50 \mu \mathrm{M} \mathrm{B}$, but there was a tendency of less negative $\Psi_{\text {leaf }}$ in Brigitta with an increase in B rates $(r=-0.51)$, whereas in Legacy plants B excess (i.e. $800 \mu \mathrm{M})$ was associated with a more negative $\Psi_{\text {leaf }}$ $(\mathrm{r}=0.60)$ in comparison to B at $0 \mu \mathrm{M}$. Similar results were reported by Gimeno et al. (2012) in lemon tree (Citrus limon Burm. F. cv. Verna) grown under B at $0.25,2,4.5$ and $7 \mathrm{mg} \mathrm{L}^{-1}$. Authors found that in plants subjected to high B (i.e 4.5 and $7 \mathrm{mg} \mathrm{L}^{-1}$ ) the water potential in leaf was decreased to more negatives values. These findings are in agreement with our experiment, which suggests that B may cause a reduction of osmotic potential regulated by compounds such as soluble sugars. However, two cultivars showed different water relation performance which would be related to a decrease in root transmembrane aquaporins in cultivar Legacy, due to physiological, biochemical and anatomical differences, aspects should be considered in the future research.

In our study, plants had foliar B concentration reached over $70 \mathrm{mg} \mathrm{B} \mathrm{kg}^{-1}$ DW in plants grown from $200 \mu \mathrm{M}$ $\mathrm{B}$ (Table 3), while plants under B deficiency $(0 \mu \mathrm{M})$, as well as those plants treated with $50 \mu \mathrm{M}$ B showed foliar B ranging from 47 to $55 \mathrm{mg} \mathrm{B} \mathrm{kg}^{-1} \mathrm{DW}$ (Table $3)$. These concentrations were reported by Wójcik (2005) as normal ranges (from 15 to $55 \mathrm{mg} \mathrm{kg}^{-1}$ DW) for B fertilized highbush blueberry plants cv. Bluecrop, whereas Sanderson et al. (2008) found leaf $\mathrm{B}$ concentration of $32 \mathrm{mg} \mathrm{kg}^{-1}$ for lowbush blueberries (Vaccinium angustifolium Ait.). Several studies have reported molecular and physiological mechanisms of B tolerance in plants and highlighted the role of root aquaporins involved in B transport to shoots, regulated by different genes in different cereal species. In the present study, higher concentration of B in leaves than roots suggested strongly B transport out of roots via plasma membrane diffusion and protein transporters (Herrera-Rodríguez et al., 2010). Similarly, Nasim et al., (2015) attributed transported-mediated B exclusion by the tolerant cultivar of barley under excessive B (and that means against the concentration gradient in the soil solution surrounding roots). 
In the study presented here, the interaction (B x cultivar) was significant regarding leaf concentration of $\mathrm{Ca}$ and $\mathrm{K}$ (Table 1). Boron and $\mathrm{Ca}$ metabolism and their localization are interrelated in several functions in plants, such as being a constituent of the cell wall and acting synergistically in the transport and accumulation of sugars in fruits (Herrera-Rodríguez et al., 2010). Leaf concentration of Ca increased in Legacy, but was not affected in Brigitta, similarly to Simón et al. (2013), who reported unaltered Ca concentration in leaves of Jatropha curcas L. seedlings under increasing B treatments. Singh et al. (2012) and Simón et al. (2013) reported similar findings in relation to an increased foliar K by B application in carrot (Daucus carota) and Jatropha curcas respectively.

In our study, the high concentration of B in the substrate was related to a decreased growth and DW yield in plants. The literature reported that B toxicity was associated with oxidative stress by its accumulation in leaf cell walls causing imbalances in cytoplasmic metabolism (Molassiotis et al., 2006; Herrera-Rodríguez et al., 2010; Landi et al., 2012). According to Herrera-Rodriguez et al. (2010) excessive B in tissues decreased plant capacity to avoid the photooxidative damage arising from the accumulation of ROS that trigger lipid peroxidation. Our study demonstrated that lipid peroxidation was increased at both low and high B in leaf and root tissues of Brigitta, whereas leaves of Legacy were more sensitive to high B $(r=0.54)$ than lower B rates, as also reported by Kayaa and Ashraf (2015) in B stressed tomato (Lycopersicon esculentum Mill.) plants. However, Tewari et al. (2010) reported that lipid peroxidation was not influenced significantly in leaves of mulberry (Morus alba L.) grown at three $\mathrm{B}$ rates.

Boron acts as a regulatory factor of the antioxidant protective system in plants (Dahajipour et al., 2011; Landi et al., 2012; Singh et al., 2012). In the present study, medium and high B rates $(50,200$ and $400 \mu \mathrm{M})$ had a greater influence on RSA in leaves than low $\mathrm{B}$, as also reported for marshmallow by Moalemi et al. (2012). However, there was no significant difference in RSA in leaves at 0 and $800 \mu \mathrm{M} \mathrm{B}$ (Figure 3), indicating that B deficiency, as well as B excess, can decrease enzymatic and non-enzymatic antioxidant capacity (Tewari et al., 2010; Singh et al., 2102).

\section{Conclusions}

In conclusion, the B addition at $50 \mu \mathrm{M}$ and $200 \mu \mathrm{M}$ increased highbush blueberry root and shoot biomass and growth rate by up to $75 \%$, particularly in cultivar Brigitta, concomitantly with improved leaf water potential. Cultivar Brigitta had higher B accumulation in root and leaves than Legacy when exposed to B excess. Both B deficiency $(0 \mu \mathrm{M})$ and B excess (400 and $800 \mu \mathrm{M})$ caused oxidative stress in leaves and roots to a greater extent in Brigitta than Legacy. Finally, the study provides evidence that an adequate B level in highbush blueberry plays an important role in plant growth and physiology; however, the responses were dependent on cultivar and $\mathrm{B}$ rate. Hence, the addition of $\mathrm{B}$ to remediate its deficiency should be managed carefully to avoid toxicity and consider the cultivar effects.

\section{Acknowledgements}

This study was supported by FONDECYT $\mathrm{N}^{\circ}$ 3140622 project from Comisión Nacional de Investigación Científica y Tecnológica (CONICYT) Chile. We thank Berries San Luis (Lautaro, Chile) for the plant material. 


\section{References}

Bañón, S., Miralles, J., Ochoa, J., Sánchez-Blanco, M.J. 2012. The effect of salinity and high boron on growth, photosynthetic activity and mineral contents of two ornamental shrubs. Hort. Sci. 39, 188-194.

Besoain, E. 1985. Mineralogía de arcillas de suelos (No. 60). Bib Orton IICA/CATIE.

Blevins, D.G., Lukaszewski, K.M. 1998. Boron in plant structure and function. Ann. Rev. Plant Physiol. Plant Mol. Biol. 49, 481-500.

Camacho-Cristóbal, J.J., Rexach, J., González-Fontes, A. 2008. Boron in Plants: Deficiency and Toxicity. J. Integr. Plant Biol. 50, 1247-1255.

Caruso, F.L., Ramsdell, D.C. 1995. Compendium of blueberry and cranberry diseases. American Phytopathological Society. $87 \mathrm{p}$.

Chilean Blueberry Committee. 2015. Posición de Chile como proovedor de arándanos en el mundo: Oportunidades y desafíos. http://http://www.cbbc. iqonsulting.com/login.php. Accessed 15 December 2015 .

Chinnici, F., Bendini, A.A., Gaiani, A., Riponi, C. 2004. Radical scavenging activities of peels and pulps from cv. Golden delicious apples as related to their phenolic composition. J. Agr. Food Chem. $52,4684-4689$.

Dahajipour, M., Ghanati, F., Fujiwara, T. 2011. Interaction between boron and aluminium and their effects on phenolic metabolism of Linum usitatissimum L. roots. Plant Physiol. Biochem. 49, 1377- 1383.

Du, Z., Bramlage, W.J. 1992. Modified thiobarbituric acid assay for measuring lipid oxidation in sugarrich plant tissue extracts. J Agric. Food Chem. 40, $1566-1570$.
Ehlenfeldt, M.K., Prior, R.L. 2001. Oxygen radical absorbance capacity (ORAC) and phenolic and anthocyanin concentrations in fruit and leaf tissues of highbush blueberry. J. Agric. Food Chem. 49, 2222-2227.

Eichholz, I., Huyskens-Keil, S., Kroh, L.W., Rohn, S. 2011. Phenolic compounds, pectin and antioxidant activity in blueberries (Vaccinium corymbosum L.) influenced by boron and mulch cover. J. Applied Bot. Food Qual. 84, 26 - 32.

Gimeno, V., Simón, I., Nieves, M., Martínez, V., Cámara-Zapata, J.M., García, A.L., García-Sánchez, F. 2012. The physiological and nutritional responses to an excess of boron by Verna lemon trees that were grafted on four contrasting rootstocks. Trees. 26, 1513-1526.

Herrera-Rodríguez, M.B., González-Fontes, A., Rexach, J., Camacho-Cristóbal, J.J., Maldonado, J.M., Navarro-Gochicoa, M.T. 2010. Role of boron in vascular plants and response mechanisms to boron stresses. Plant Stress 4 (Special Issue 2), 115-122.

Hoffmann, W.A., Poorter, H. 2002. Avoiding bias in calculations of relative growth rate. Ann Bot. 90, $37-42$.

Kayaa, C., Ashraf, M. 2015. Exogenous application of nitric oxide promotes growth and oxidative defense system in highly boron stressed tomato plants bearing fruit. Sci. Hortic. 185, 43-47.

Landi, M., Degl'Innocenti, E., Pardossi. A., Guidi, L. 2012. Antioxidant and photosynthetic responses in plants under boron toxicity: A review. American Journal of Agricultural and Biological Sciences. 7, 255-270.

Liu, G., Dong, X., Liu, L., Wu, L., Peng, S., Jiang, C. 2014. Boron deficiency is correlated with changes in cell wall structure that lead to growth defects in the leaves of navel orange plants. Sci. Hortic. 176, 54-62. 
Meriño-Gergichevich, C., Ondrasek, G., Zovko, M., Šamec, D., Alberdi, M., Reyes-Díaz, M. 2015. Comparative study of methodologies to determine the antioxidant capacity of Al-toxified blueberry amended with calcium sulfate. J. Soil Sci. Plant Nutr. 15, 965-978.

Miwa, K., Fujiwara, T. 2010. Boron transport in plants: co-ordinated regulation of transporters. Ann. Bot. 105, 1103-1108.

Moalemi, R., Aghdasi, M., Ghanati, F. 2012. Induction of phenolic compounds is affected by boron supply in Marshmallow (Althaea officinalis L.) cells. Progress in Biological Sciences 2, 68-75.

Molassiotis, A., Sotiropoulos, T., Tanou, G., Diamantidis, G., Therios, I. 2006. Boron-induced oxidative damage and antioxidant and nucleolytic responses in shoot tips culture of the apple rootstock EM 9 (Malus domestica Borkh). Environ. Exp. Bot. 56, 54-62.

Nable, R.O., Bañuelos, G.S., Paull, J.G. 1997. Boron toxicity. Plant Soil. 193, 181-198.

Nasim, M., Rengel, Z., Aziz, T., Dev Regm, B., Saqib, M. 2015. Boron toxicity alleviation by zinc application in two barley cultivars differing in tolerance to boron toxicity. Pak J Agri Sci 52, 151-158.

Pandey, N., Archana. 2013. Antioxidant responses and water status in Brassica seedlings subjected to boron stress. Acta Physiol. Plant. 35, 697-706.

Sadzawka, A., Grez, R., Carrasco, M., Mora, M. 2007. Métodos de análisis de tejidos vegetales. Santiago. Chile. Comisión de Normalización y Acreditación Sociedad Chilena de la Ciencia del Suelo. 53p.

Sanderson, K., Eaton, L., Melanson, M., Wyand, S., Fillmore, S., Jordan, C. 2008. Maritime provinces wild blueberry fertilizer study'. International Journal of Fruit Science. 8, 52-62.
Seguel, A., Castillo, C.G., Morales, A.P., Campos, P., Cornejo, P., Borie, F. 2016. Arbuscular mycorrhizal symbiosis in four Al-tolerant wheat genotypes grown in an acidic Andisol. J. Soil Sci. Plant Nutr. $16,164-173$.

Shorrocks, V.M. 1997. The occurrence and correction of boron deficiency. Plant Soil. 193, 121-148.

Simón, I., Díaz-López, L., Gimeno, V., Nieves, M., Pereira, W.E., Martínez, V., Lidon, V., GarcíaSánchez, F. 2013. Effects of boron excess in nutrient solution on growth, mineral nutrition, and physiological parameters of Jatropha curcas seedlings. J. Plant Nutr. Soil Sci. 176, 165-174.

Singh, D.P., Beloy, J., McInerney, J.K., Day, L. 2012. Impact of boron, calcium and genetic factors on vitamin $\mathrm{C}$, carotenoids, phenolic acids, anthocyanins and antioxidant capacity of carrots (Daucus carota). Food Chem. 132, 1161-1170.

Tewari, R.K., Kumar, P., Sharma, P.N. 2010. Morpholgy and oxidative physiology of boron-deficient mulberry plants. Tree physiol. 30, 68-77.

Wimmer, M.A., Eichert, T. 2013. Review: Mechanisms for boron deficiency-mediated changes in plant water relations. Plant Sci. 203-204, 25-32

Wójcik, P., Filipczak, J. 2015. Response of 'White Smith' gooseberry to boron fertilization under conditions of low soil boron availability. Sci. Hortic. $197,366-372$.

Wójcik, P. 2005. Response of 'Bluecrop' highbush blueberry to boron fertilization. J. Plant Nutr. 28, 1897-1906.

Yadegari, M. 2016. Effect of micronutrients foliar application and biofertilizers on essential oils of lemon balm. J. Soil Sci. Plant Nutr. 16, 702-715. 